\title{
Factors affecting life expectancy in Kazakhstan
}

\author{
A.Zh. Panzabekova $\bowtie$, I.E. Digel \\ Institute of Economics of the Science Committee of the Ministry of Education and Science of the Republic of Kazakhstan, \\ Almaty, Kazakhstan; panzabekova.aksana@ieconom.kz
}

\begin{abstract}
Relevance. Life expectancy is a comprehensive indicator reflecting the quality of life in a country or region, which is why it is important to estimate the impact of various socio-economic factors on this indicator as accurately as possible. Our study makes a novel contribution to the existing research by conducting a correlation and regression analysis of factors affecting life expectancy in regions of Kazakhstan based on panel data. Research objective. This paper aims to present a modified methodology for estimation of factors affecting life expectancy in regions of Kazakhstan. Data and methods. Our research relies on panel data on regions and cities of Kazakhstan. The data are provided by the Ministry of National Economy and the Ministry of Health Care of the Republic of Kazakhstan. Methodologically, the research is based on regression and correlation analysis. The two main criteria were applied for data selection: availability of statistical data for a sufficiently long period and the potential impact of factors on life expectancy. We built a two-factor power regression model calculated with the help of software package Microsoft Excel. Results. In our research, regression models were used to formulate conclusions concerning the impact of certain socio-economic factors on life expectancy in regions of Kazakhstan. We also brought to light the factors whose relationship to life expectancy requires further investigation. Conclusions. It was found that the most significant factors affecting life expectancy in regions of Kazakhstan are economic ones. The proposed methodology can be used for short- and medium-term predictions of life expectancy.
\end{abstract}

\section{KEYWORDS}

life expectancy, quality of life, nominal monetary income, subsistence minimum, poverty, unemployment level, morbidity rate

\section{FOR CITATION}

Panzabekova, A.Zh., Digel, I.E. (2020) Factors affecting life expectancy in Kazakhstan. R-economy, 6(4), 261-270. doi: $10.15826 /$ recon.2020.6.4.023

\section{Факторы, влияющие на ожидаемую продолжительность жизни в Казахстане}

\author{
А.Ж. Панзабекова $\bowtie$, И.Е. Дигель \\ Институт экономики Комитета науки Министерства образования и науки, Алмать, Казахстан; \\ panzabekova.aksana@ieconom.kz
}

\section{АННОТАЦИЯ}

Актуальность. Ожидаемая продолжительность жизни - это многосторонний показатель, отражающий качество жизни в стране или регионе, поэтому важно как можно точнее оценить влияние различных социально-экономических факторов на него. Наше исследование вносит новый вклад в существующие исследования, проводя корреляционный и регрессионный анализ факторов, влияющих на продолжительность жизни в регионах Казахстана, на основе панельных данных. Цель исследования. Исследование нацелено на разработку новой методологии для оценки факторов, влияющих на продолжительность жизни в регионах Казахстана. Данные и методы. Наше исследование опирается на панельные данные по регионам и городам Казахстана. Данные предоставлены Министерством национальной экономики и Министерством здравоохранения Республики Казахстан. Методологически исследование основано на регрессионном и корреляционном анализе. При отборе данных использовались два основных критерия: наличие статистических данных за достаточно длительный период и возможное влияние факторов на продолжительность жизни. Мы построили двухфакторную модель регрессии мощности, рассчитанную с помощью Microsoft Excel. Результаты. В нашем исследовании на основе регрессионных моделей сформулированы выводы о влиянии

\section{КЛЮЧЕВЫЕ СЛОВА}

ожидаемая продолжительность жизни, качество жизни, номинальные денежные доходы, прожиточный минимум, уровень бедности, уровень безработицы, заболеваемость 
тех или иных социально-экономических факторов на продолжительность жизни в регионах Казахстана. Мы также выявили факторы, связь которых с ожидаемой продолжительностью жизни требует дальнейшего изучения. Выводы. Выявлено, что наиболее существенными факторами, влияющими на продолжительность жизни в регионах Казахстана, являются экономические. Предлагаемая методика может быть использована для краткосрочного и среднесрочного прогнозирования продолжительности жизни.

\section{ДЛЯ ЦИТИРОВАНИЯ}

Panzabekova, A.Zh., Digel, I.E. (2020) Factors affecting life expectancy in Kazakhstan. R-economy, 6(4), 261-270. doi: 10.15826/recon.2020.6.4.023

\section{Introduction}

Life expectancy is one of the key indicators of the quality of life, encompassing a multitude of different factors. Analysis of these factors is thus necessary to bring to light those with the strongest impact and devise state policies to improve the quality of life in the country. The extent of this or that factor's influence may vary across regions, which means that such studies may need to analyze regional data.

Our research is aimed at analyzing the relationships between life expectancy and a set of social, economic and medical factors in regions of Kazakhstan. We intended to explore the connections between specific factors and life expectancy, factors peculiar to specific regions and possibilities of forecasting life expectancy by building models that would take into consideration the most important factors. To this end, we modified the methodology proposed by Molchanova and Kruchek (2013) to make it suitable for evaluation of factors affecting life expectancy in Kazakhstan.

Our research objectives are as follows:

- to select indicators that may affect life expectancy;

- to reveal the relationships between these factors and life expectancy in specific regions of Kazakhstan;

- to identify the factors with the strongest influence for each region;

- to formulate recommendations for extending life expectancy.

To address these goals, we selected indicators that may influence life expectancy in regions of Kazakhstan. Furthermore, for each region and for each indicator we calculated coefficients of their correlation with life expectancy, thus excluding the indicators with coefficients below the threshold value. To identify the factors with the strongest influence on life expectancy we built two-factor power regression models based on the Cobb-Douglas production function. The results of our regression and correlation analysis have led us to formulate recommendations concerning measures to increase life expectancy.

\section{Literature review}

Factors affecting life expectancy have gained much attention on the part of social scholars and economists, who sought to elaborate guidelines for improvement of relevant state policies.

A variety of methods is used to select the factors for analysis and to estimate their impact on life expectancy. There are numerous studies using different models to analyze the impact of environmental and medical factors on life expectancy. For example, Leliveld et al. (2020) explore the impact of human exposure to fine particulate matter (PM2.5) in the air on life expectancy by applying a novel Global Exposure Mortality Model (GEMM).

Zaninotto et al. (2020) consider the impact of bad habits such as smoking, alcohol drinking, low physical activity and overeating on longevity. They use statistical analysis, more specifically, multistate life table models on longitudinal data to reveal these interconnections.

Srour et al. (2020) used a multiadjusted parametric proportional hazard model to predict life expectancy by using lifestyle factors as predictor variables.

A large team of researchers led by Murray and Vollset (2018) conducted a large-scale cross-national study covering 195 countries to forecast life expectancy, years of life lost, all-cause and cause-specific mortality for 250 causes of death by generating health scenarios.

Cervantes et al. (2020) analyzed the relationship between life expectancy and socio-economic factors with the help of econometric methods called 'random decision forests'. As a result, they identified the key factors that have a significant influence on life expectancy and proposed measures for extending life expectancy.

As for post-Soviet countries, there is a large body of research on the factors affecting life expectancy in Russia. For example, Glushakov (2004) estimates the general level of life expectancy, identifies specific components of this indicator and calculates the elimination reserve between the real and some hypothetical levels of 
life expectancy to reveal hidden reserves for increasing life expectancy by improving the quality of health care.

Shabunova, Rybakova and Tikhomirova from the Institute of Socio-Economic Studies of Population of the Russian Academy of Sciences (ISESP RAS) concentrated on the case of Vologda region to evaluate the influence of a set of factors on life expectancy by applying the correlation analysis method (2009). These estimates were compared with those of 'subjective health' in relation to different socio-economic criteria, leading to conclusions about the public health and dynamics of the quality of life in Vologda region.

Timashev, Voronina and Makarova considered the notion of average life expectancy and evaluated the impact of infrastructure factors on its dynamics (2013). They also proposed their own approach based on correlation and regression analysis to evaluating quantitative correlations between these indicators.

Novoselova (2016) studied the main factors of life expectancy in big cities by looking at regional differences in the dynamics of socio-economic indicators, in particular health care. As a result, the key factors that have a negative influence on the growth of life expectancy in Moscow were identified.

In general, our review of the research literature shows that the vast majority of the above-mentioned and similar studies (Kabanov, 2015; Andrianov, 2019; Kulak, 2016; Zvezdina \& Ivanova, 2015) use mathematical methods to estimate the impact of various factors on life expectancy. Such choice of methods can be explained by the fact that they allow researchers to analyze large amounts of data and reveal hidden patterns. These studies put the main emphasis on medical factors such as morbidity rates of diseases, habits and lifestyle (for example, alcohol consumption habits), and cause-specific mortality. There are also studies analyzing the impact of environmental and economic factors. All of the above influenced the structure and logic of this study.

Our review of the contemporary research on life expectancy in Kazakhstan has shown that such studies use a limited range of methods. For example, Omarova et al. (2019) rely on commonly accepted indicators such as the life expectancy coefficient. Sraubaev et al. (2013) investigated ways of extending life expectancy by analyzing environmental indicators and calculating the air pollution index on the basis of statistical data. Taskinbajkyzy et al. (2019) analyzed the impact of morbidity on the quality of life in Kazakhstan, including life expectancy. Most of these studies are based on the calculation of population health indices.

There is a considerable number of review articles which summarize the existing research on this topic. For example, Palevskaya et al. (2019) analyzed the quality of life in the context of the state program 'Densaulyk' (Health). Shelomentseva et al. (2019) consider the possible impact of the state policy in health care on the quality of life and life expectancy. Baykova (2018) analyzed the connection between life expectancy and the country's economic security. Rakhmetova and Andekina (2018) highlighted the need to investigate life expectancy in specific regions but did not offer any in-depth analysis of this matter. Esenbekova (2017) used time series regression equations to forecast life expectancy in Kazakhstan and Kyrgyzstan. Nurlanova et al. (2019) discuss the prospects of regional socio-economic development in Kazakhstan and their analysis includes life expectancy as an indicator.

Thus, so far no evaluations of the factors affecting life expectancy in Kazakhstan have been made that would be based on correlation and regression analysis of data by region. Our study aims to address this research gap.

\section{Methodology}

Our analysis of the factors affecting life expectancy in regions of Kazakhstan relies on the methodology developed by Russian scholars Molchanova and Kruchek (2013). Several adjustments were made to adapt certain statistical indicators for evaluation of the factors shaping life expectancy. In particular we decided not to apply the 'correlation pleiad' method since we did not intend to look for the relationships between all the factors but instead wanted to focus on the influence of specific factors on just one indicator - life expectancy. Furthermore, the data we had for the given time period led us to choose indicators that differed from those included in the original methodology. The regression model was calculated by applying the least squares method for linear regression, we used logarithmic indicator values to transform the results into a power function.

Our research methodology relies on the following:

1) a set of socio-economic, environmental and medical indicators that formed the primary set of factors based on panel (longitudinal) data; 
2) calculation of correlation coefficients to select the main factors affecting life expectancy;

3 ) the use of regression models for evaluation of factors affecting life expectancy.

The main sources of data were the web-sites of the Committee on Statistics of the Ministry of National Economy of the Republic of Kazakh$\operatorname{stan}^{1}$, information service of the Committee on the Legal Statistics and Special Accounts of the State Office of Public Prosecutor of the Republic of Kazakhstan ${ }^{2}$, and the Republican Center for Health Development ${ }^{3}$. The key criterion for data selection was their availability for the given time period - from 2001 to 2018. For the sake of data homogeneity, we considered the statistics for Turkestan region and the city of Shymkent as one indicator since these two regions used to be a part of South Kazakhstan region.

\section{Results}

In Kazakhstan, life expectancy increased by 7.35 years between 2001 to 2018 - from 65.80 in 2001 to 73.15 in 2018. This indicator varies across regions, with the maximum value in the city of Nur Sultan - 76.21 years in 2018 - and the minimum in North Kazakhstan region - 71.14.

As Table 1 illustrates, life expectancy in Nur-Sultan and Almaty shows the highest positive deviation from the mean while life expectancy in North Kazakhstan, Akmola and Karaganda regions shows the highest negative deviation.

Our primary set of factors comprises 13 factors with correlation coefficient values above the threshold of 0.7 , that is, these are the factors showing a strong correlation with life expectancy. It should be noted that in different regions of Kazakhstan correlation coefficients for the same

\footnotetext{
${ }^{1}$ Labour and Employment Statistics. Official Web-Site of the Committee on Statistics of Ministry of National Economy of the Republic of Kazakhstan. Retrieved from: https:// stat.gov.kz/official/industry/25/statistic/8 ; Price Statistics. Official Web-site of the Committee on Statistics of Ministry of National Economy of the Republic of Kazakhstan. Retrieved from: https://stat.gov.kz/official/industry/26/statistic/8 ; Demographic Statistics. Retrieved from: https://stat.gov.kz/official/industry/61/statistic/8; Quality of Life Statistics. Retrieved from: https://stat.gov.kz/official/industry/64/statistic/8

2 Statistical Reports. Information Service of the Committee on the Legal Statistics and Special Accounts of the State Office of Public Prosecutor of the Republic of Kazakhstan. Retrieved from: https://qamqor.gov.kz/portal/page/portal/POPageGroup/Services/Pravstat

3 Statistical yearbooks 'Public Health in the Republic of Kazakhstan and Activities of Health Care Organizations'. Republican Center for Health Development. Retrieved from: $\underline{\text { http://www.rcrz.kz/index.php/ru/?option=com con- }}$ tent\&view $=$ article\&id $=973$
}

factor could be different and in some cases this or that factor had to be excluded from the set of factors that affected life expectancy in a particular region while in other regions this factor remained important. Moreover, the factors were evaluated for multicollinearity. In some cases, factors with direct or functional relationships were removed, in others, we kept some of the factors (e.g. poverty and unemployment) to ensure the quality of our regression models. There are, however, no regression models with overlapping collinear factors, that is, the quality of the models did not suffer.

Life expectancy by region (years)

\begin{tabular}{|l|c|c|c|c|}
\hline \multicolumn{1}{|c|}{ Region } & $\mathbf{2 0 0 1}$ & $\mathbf{2 0 1 8}$ & $\begin{array}{c}\mathbf{2 0 0 8} \text { in } \\
\text { relation } \\
\text { to 2001 }\end{array}$ & $\begin{array}{c}\text { Devia- } \\
\text { tion from } \\
\text { the mean }\end{array}$ \\
\hline City of Nur-Sultan & 69.05 & 76.21 & 7.16 & +3.06 \\
\hline City of Almaty & 68.41 & 75.54 & 7.13 & +2.39 \\
\hline $\begin{array}{l}\text { Turkestan region and } \\
\text { Shymkent }\end{array}$ & 67.39 & 73.8 & 6.41 & +0.65 \\
\hline Mangystau region & 63.34 & 73.73 & 10.39 & +0.58 \\
\hline Aktobe region & 63.88 & 73.45 & 9.57 & +0.3 \\
\hline Almaty region & 67.42 & 73.44 & 6.02 & +0.29 \\
\hline Republic of Kazakhstan & 65.8 & 73.15 & 7.35 & 0 \\
\hline Atyrau region & 64.93 & 73.13 & 8.2 & -0.02 \\
\hline Kyzylorda region & 65.78 & 72.98 & 7.2 & -0.17 \\
\hline Jambyl region & 66.43 & 72.79 & 6.36 & -0.36 \\
\hline West Kazakhstan region & 65.05 & 72.43 & 7.38 & -0.72 \\
\hline Kostanay region & 65.71 & 72.36 & 6.65 & -0.79 \\
\hline Pavlodar region & 64.95 & 72.31 & 7.36 & -0.84 \\
\hline East Kazakhstan region & 65.21 & 71.97 & 6.76 & -1.18 \\
\hline Karaganda region & 64.16 & 71.7 & 7.54 & -1.45 \\
\hline Akmola region & 63.31 & 71.6 & 8.29 & -1.55 \\
\hline $\begin{array}{l}\text { North Kazakhstan } \\
\text { region }\end{array}$ & 65.14 & 71.14 & 6 & -2.01 \\
\hline \multicolumn{1}{|c|}{ Source compion } & & & & \\
\hline
\end{tabular}

Source: compiled by using the data from the Statistical Bulletin 'Life Expectancy'. Demographic Statistics. Official Web-Site of the Committee on Statistics of Ministry of National Economy of the Republic of Kazakhstan. Retrieved from: https://stat.gov.kz/api/getFile/?docId=ESTAT357289

For easier software data processing, each factor was coded the following way: NMI, the nominal monetary income; SM, subsistence minimum; NISM, ratio of nominal income to subsistence minimum; HW, the number of health workers; $\mathrm{DpM}$, the number of divorces per 1,000 marriages; $\mathrm{P}$, poverty level; $\mathrm{U}$, the rate of unemployment; $\mathrm{CMR}$, the rate of cancer morbidity; $\mathrm{BD}$, the rate of blood diseases; $\mathrm{MD}$, the rate of substance-induced mental disorders; CSD, morbidity rates of circulatory system diseases; $\mathrm{RD}$, respiratory disease morbidity rate; and CR, crime rates. 
For each of these factors we calculated correlation coefficients for each specific region and then ranked the factors in descending order depending on their their correlation coefficients in modulus (that is, regardless of the coefficient's positive or negative sign). At this stage we excluded the factors whose correlation coefficients in modulus did not exceed 0.7. Thus we were able to identify the factors that have the most impact on life expectancy in each region.

The factors were grouped by macro-region to identify those that occur most frequently and have a high correlation. The results are shown in Table 2.

As Table 2 shows, such socio-economic indicators as nominal per capita income, subsistence minimum, poverty level, and unemployment correlate with life expectancy in all the regions of $\mathrm{Ka}$ zakhstan.

In many regions, there are correlations between such indicators as the ratio of divorces to marriages, the ratio of nominal income to subsistence minimum, and the rate of substance-induced mental disorders. Such regions as the
North, East and Centre of Kazakhstan have a high incidence of cancer and blood disorders.

Table 2

Frequency of factors, by macro-region

\begin{tabular}{|c|c|c|c|c|}
\hline $\begin{array}{l}\text { Macro-re- } \\
\text { gion }\end{array}$ & $\begin{array}{c}\text { South } \\
\text { (5 regions) }\end{array}$ & $\begin{array}{c}\text { North } \\
\text { (5 regions) }\end{array}$ & $\begin{array}{c}\text { West } \\
\text { (4 regions) }\end{array}$ & $\begin{array}{c}\text { East and } \\
\text { Centre } \\
\text { (2 regions) }\end{array}$ \\
\hline $\begin{array}{l}\text { In all } \\
\text { regions }\end{array}$ & $\begin{array}{c}\text { NMI, SM, } \\
\text { NISM, } \\
\text { P, U }\end{array}$ & $\begin{array}{l}\text { NMI, SM, } \\
\text { P, U }\end{array}$ & $\begin{array}{c}\text { NMI, SM, } \\
\text { P, U }\end{array}$ & $\begin{array}{l}\text { NMI, SM, } \\
\text { NISM, P, U, } \\
\text { DpM, BD, } \\
\text { MD, CSD }\end{array}$ \\
\hline $\begin{array}{l}\text { In most } \\
\text { regions }\end{array}$ & $\begin{array}{c}\mathrm{HW} \\
\mathrm{DpM}, \\
\mathrm{MD}, \mathrm{CSD}\end{array}$ & $\begin{array}{c}\text { NISM, } \\
\text { DpM, } \\
\text { CMR, } \\
\text { MD, CSD, } \\
\text { CR }\end{array}$ & $\begin{array}{c}\text { NISM, } \\
\text { HW }\end{array}$ & \\
\hline $\begin{array}{l}\text { In less } \\
\text { than } 50 \% \\
\text { of regions }\end{array}$ & $\begin{array}{l}\text { CMR, } \\
\mathrm{RD}, \mathrm{CR}\end{array}$ & $\mathrm{HW}, \mathrm{BD}$ & $\begin{array}{c}\text { CR, CSD, } \\
\text { RD }\end{array}$ & CR \\
\hline $\begin{array}{l}\text { In none of } \\
\text { the regions }\end{array}$ & $\mathrm{BD}$ & & CMR, BD & $\begin{array}{c}\text { HW, CMR, } \\
\text { RD }\end{array}$ \\
\hline
\end{tabular}

We compiled ranking tables (Tables 3-6) to show which factors were the most important for which region. The factors for each region are arranged in descending order of the regression coefficients in modulus.

Correlations between factors and life expectancy in regions of Kazakhstan

\begin{tabular}{|c|c|c|c|c|c|c|c|}
\hline $\begin{array}{c}\text { Akmola } \\
\text { region }\end{array}$ & $\begin{array}{c}\text { Correlation } \\
\text { coefficient }\end{array}$ & $\begin{array}{c}\text { Aktobe } \\
\text { region }\end{array}$ & $\begin{array}{c}\text { Correlation } \\
\text { coefficient }\end{array}$ & $\begin{array}{c}\text { Almaty } \\
\text { region }\end{array}$ & $\begin{array}{c}\text { Correlation } \\
\text { coefficient }\end{array}$ & $\begin{array}{c}\text { Atyrau } \\
\text { region }\end{array}$ & $\begin{array}{c}\text { Correlation } \\
\text { coefficient }\end{array}$ \\
\hline DpM & 0.958 & NMI & 0.977 & MD & -0.907 & NMI & 0.953 \\
\hline MD & -0.954 & SM & 0.973 & SM & 0.885 & SM & 0.948 \\
\hline U & -0.928 & P & -0.959 & HW & 0.884 & P & -0.936 \\
\hline SM & 0.914 & U & -0.955 & DpM & 0.884 & U & -0.893 \\
\hline NMI & 0.904 & NISM & 0.916 & NMI & 0.883 & HW & 0.885 \\
\hline P & -0.888 & RD & -0.909 & P & -0.879 & NISM & 0.879 \\
\hline NISM & 0.867 & MD & -0.832 & CR & 0.854 & DpM & 0.854 \\
\hline CR & 0.831 & HW & 0.818 & NISM & 0.849 & MD & -0.802 \\
\hline RD & 0.743 & & & U & -0.836 & CSD & 0.789 \\
\hline CSD & 0.713 & & & CMR & -0.784 & CR & 0.768 \\
\hline
\end{tabular}

Note: 'correlation coefficient' shows the correlation between the factor and the region's life expectancy.

The same codes were used to denote the factors as in Table 2.

Table 4

Correlations between factors and life expectancy in regions of Kazakhstan

\begin{tabular}{|c|c|c|c|c|c|c|c|}
\hline $\begin{array}{c}\text { Western } \\
\text { Kazakhstan }\end{array}$ & $\begin{array}{c}\text { Correlation } \\
\text { coefficient }\end{array}$ & $\begin{array}{c}\text { Jambyl } \\
\text { region }\end{array}$ & $\begin{array}{c}\text { Correlation } \\
\text { coefficient }\end{array}$ & $\begin{array}{c}\text { Karaganda } \\
\text { region }\end{array}$ & $\begin{array}{c}\text { Correlation } \\
\text { coefficient }\end{array}$ & $\begin{array}{c}\text { Kostanay } \\
\text { region }\end{array}$ & $\begin{array}{c}\text { Correlation } \\
\text { coefficient }\end{array}$ \\
\hline NMI & 0.964 & CMR & 0.924 & MD & -0.921 & MD & -0.920 \\
\hline SM & 0.949 & SM & 0.907 & SM & 0.918 & DpM & 0.902 \\
\hline P & -0.938 & NMI & 0.888 & DpM & 0.903 & SM & 0.876 \\
\hline U & -0.930 & DpM & 0.866 & NMI & 0.902 & U & -0.874 \\
\hline MD & -0.892 & U & -0.861 & P & -0.890 & NMI & 0.872 \\
\hline NISM & 0.865 & RD & 0.856 & U & -0.872 & P & -0.829 \\
\hline CR & 0.865 & HW & 0.845 & CSD & 0.826 & CMR & 0.819 \\
\hline DpM & 0.826 & P & -0.825 & BD & -0.815 & NISM & 0.803 \\
\hline & & NISM & 0.813 & NISM & 0.800 & BD & -0.776 \\
\hline & & CSD & 0.770 & CR & 0.700 & CR & 0.697 \\
\hline
\end{tabular}

Note: 'correlation coefficient' shows the correlation between the factor and the region's life expectancy.

The same codes were used to denote the factors as in Table 2. 
Correlations between factors and life expectancy in regions of Kazakhstan

\begin{tabular}{|c|c|c|c|c|c|c|c|}
\hline $\begin{array}{c}\text { Kyzylorda } \\
\text { region }\end{array}$ & $\begin{array}{c}\text { Correlation } \\
\text { coefficient }\end{array}$ & $\begin{array}{c}\text { Mangistau } \\
\text { region }\end{array}$ & $\begin{array}{c}\text { Correlation } \\
\text { coefficient }\end{array}$ & $\begin{array}{c}\text { Pavlodar } \\
\text { region }\end{array}$ & $\begin{array}{c}\text { Correlation } \\
\text { coefficient }\end{array}$ & $\begin{array}{c}\text { Northern } \\
\text { Kazakhstan }\end{array}$ & $\begin{array}{c}\text { Correlation } \\
\text { coefficient }\end{array}$ \\
\hline DpM & 0.937 & $\mathbf{U}$ & -0.979 & MD & -0.971 & DpM & 0.952 \\
\hline P & -0.910 & MD & -0.978 & NMI & 0.929 & P & -0.889 \\
\hline SM & 0.907 & SM & 0.975 & CMR & 0.928 & SM & 0.888 \\
\hline U & -0.898 & NMI & 0.969 & SM & 0.920 & NMI & 0.883 \\
\hline NMI & 0.894 & HW & 0.948 & U & -0.912 & U & -0.870 \\
\hline MD & -0.847 & $\mathbf{P}$ & -0.945 & NISM & 0.908 & NISM & 0.849 \\
\hline HW & 0.831 & & & P & -0.895 & MD & -0.842 \\
\hline NISM & 0.824 & & & CSD & 0.869 & CMR & 0.836 \\
\hline & & & & RD & 0.854 & RD & 0.808 \\
\hline & & & & DpM & 0.843 & CR & 0.765 \\
\hline & & & & & & CSD & 0.737 \\
\hline & & & & & & HW & 0.708 \\
\hline
\end{tabular}

Note: 'correlation coefficient' shows the correlation between the factor and the region's life expectancy.

The same codes were used to denote the factors as in Table 2.

Correlations between factors and life expectancy in regions of Kazakhstan

\begin{tabular}{|c|c|c|c|c|c|c|c|}
\hline $\begin{array}{c}\text { Turkestan region } \\
\text { and Shymkent }\end{array}$ & $\begin{array}{c}\text { Correlation } \\
\text { coefficient }\end{array}$ & $\begin{array}{c}\text { Eastern } \\
\text { Kazakhstan }\end{array}$ & $\begin{array}{c}\text { Correlation } \\
\text { coefficient }\end{array}$ & Nur-Sultan & $\begin{array}{c}\text { Correlation } \\
\text { coefficient }\end{array}$ & $\begin{array}{c}\text { Almaty } \\
\text { Correlation } \\
\text { coefficient }\end{array}$ \\
\hline SM & 0.927 & CSD & 0.965 & NMI & 0.978 & SM & 0.927 \\
\hline NMI & 0.903 & U & -0.937 & HW & 0.975 & NMI & 0.918 \\
\hline DpM & 0.887 & NMI & 0.907 & SM & 0.974 & U & -0.911 \\
\hline P & -0.877 & SM & 0.906 & U & -0.960 & HW & 0.894 \\
\hline U & -0.871 & NISM & 0.882 & P & -0.852 & P & -0.843 \\
\hline NISM & 0.782 & BD & -0.873 & CMR & 0.827 & CSD & 0.827 \\
\hline CSD & 0.765 & P & -0.862 & CR & 0.699 & CR & 0.796 \\
\hline MD & -0.763 & MD & -0.739 & CSD & 0.698 & NISM & 0.757 \\
\hline & & DpM & 0.725 & & & & \\
\hline
\end{tabular}

Note: 'correlation coefficient' shows the correlation between the factor and the region's life expectancy.

The same codes were used to denote the factors as in Table 2.

Our analysis shows that different regions may have a different relationship between certain factors and life expectancy: sometimes this or that factor may have a strong correlation with life expectancy while in other regions it would not even reach the threshold value of 0.7 .

The picture in some regions is quite unusual. For example, in West Kazakhstan, the level of crime has a positive correlation with life expectancy while in Jambyl and Pavlodar regions, life expectancy is positively correlated with cancer morbidity. In East Kazakhstan, life expectancy has a positive correlation with the morbidity rate of circulatory system diseases. In such cases we may suppose that there is a factor that was left unaccounted for in the analysis. In other words, there might be a factor that has a positive influence on life expectancy and at the same time on the above-mentioned factors. For instance, income growth (which, as we see, often has a positive impact on life expectancy) can result in people consuming more unhealthy food and thus lead to an increase in the incidence of a disease. Such connections make no socio-economic or medical sense, which is why they were excluded from our regression analysis. However, they can become a subject of further research.

In different regions the same indicator may exert a directly opposite influence. For example, quite expectedly, the level of unemployment in Kyzylorda region has an inverse relationship with life expectancy: a drop in unemployment causes a rise in life expectancy and vice versa. At the same time in Atyrau region, these two indicators have 
a direct relationship, which does not make much sense. In such situations the intervening variable should be excluded from the regression analysis since this variable itself can be influenced by other factors that are not considered in this study due to the absence of data or for other reasons.

For each region we built a regression model based on the modified Cobb-Douglas production function $\left[{ }^{\mathrm{i}}\right]$ :

$$
Y=b_{0} \cdot X_{1}^{b_{1}} \cdot X_{2}^{b_{2}}
$$

where $Y$ is the value of life expectancy in the given region; $b_{0}, b_{1}, b_{2}$ are the regression coefficients calculated with the help of the least squares method for the logarithms of factors; and $X_{1} и X_{2}$ are independent variables.

For each region, independent variables were chosen by the forward selection method. At the first stage, we selected the variable that had the strongest correlation with life expectancy. After that, we calculated Fisher's f-statistic for the resulting model to estimate its significance: if the model is significant, one more variable is added and the F-statistic is calculated. For each variable, Student's t-distribution was computed to assess its significance for the model (Kabanov, 2015). Afterwards, out of all the possible combinations we chose the one that generated the best model.

For each region, the number of observations was 18 while to support one independent variable, 7-10 observations are needed. Thus, our regression model could not include more than two independent variables. Therefore, for each region we built a two-factor regression model (see Table 7). The only exception is the city of Nur-Sultan, for which we have not found a second factor that would improve the quality of the model and have acceptable estimates of the model's quality.

Table 7

Parameters of life expectancy regression models for regions of Kazakhstan

\begin{tabular}{|c|c|c|c|c|c|c|c|}
\hline \multirow{2}{*}{$\begin{array}{c}\text { Parameters } \\
\text { Region }\end{array}$} & \multicolumn{2}{|c|}{ Variables } & \multicolumn{3}{|c|}{ Regression coefficients (ln) } & \multirow{2}{*}{$\begin{array}{l}\text { Standard } \\
\text { error }\end{array}$} & \multirow[t]{2}{*}{ Standardized $R^{2}$} \\
\hline & $X_{1}$ & $X_{2}$ & $b_{0}$ & $b_{1}$ & $b_{2}$ & & \\
\hline Akmola region & DpM & $\mathrm{MD}$ & 3.69 & 0.11 & -0.03 & 0.01 & 0.94 \\
\hline Aktobe region & NMI & SM & 3.5 & 0.05 & 0.02 & 0.01 & 0.95 \\
\hline Almaty region & $\mathrm{MD}$ & DpM & 3.9 & -0.04 & 0.8 & 0.007 & 0.95 \\
\hline Atyrau region & NMI & DpM & 3.36 & 28.8 & 0.041 & 0.01 & 0.96 \\
\hline Western Kazakhstan & NMI & DpM & 3.38 & 0.04 & 0.075 & 0.006 & 0.96 \\
\hline Jambyl region & CMR & $\mathrm{SM}$ & 3.59 & 0.03 & 0.065 & 0.006 & 0.96 \\
\hline Karaganda region & $\mathrm{MD}$ & SM & 4 & -0.03 & 0.04 & 0.01 & 0.94 \\
\hline Kostanay region & $\mathrm{MD}$ & DPM & 3.6 & -0.04 & 0.13 & 0.01 & 0.9 \\
\hline Kyzylorda region & DpM & $\mathrm{U}$ & 3.8 & 0.08 & -0.04 & 0.01 & 0.9 \\
\hline Mangistau region & $\mathrm{U}$ & $\mathrm{MD}$ & 4.64 & -0.09 & -0.04 & 0.01 & 0.96 \\
\hline Pavlodar region & $\mathrm{MD}$ & $\mathrm{DpM}$ & 4.09 & -0.035 & 0.056 & 0.008 & 0.96 \\
\hline Northern Kazakhstan & DpM & $\mathrm{MD}$ & 3.62 & 0.12 & -0.028 & 0.007 & 0.95 \\
\hline $\begin{array}{l}\text { Turkestan region and } \\
\text { Shymkent }\end{array}$ & SM & NMI & 3.66 & 0.13 & -0.06 & 0.01 & 0.88 \\
\hline Eastern Kazakhstan & CSD & $\mathrm{BD}$ & 3.83 & 0.12 & -0.07 & 0.005 & 0.97 \\
\hline Nur-Sultan & NMI & no data & 3.83 & 0.039 & no data & 0.006 & 0.95 \\
\hline Almaty & SM & HW & 2.73 & 0.039 & 0.012 & 0.009 & 0.95 \\
\hline
\end{tabular}

Note: 'standard error' stands for the model's standard error.

Note: standardized $\mathrm{R}^{2}$ stands for the standardized coefficient of determination.

Note: each of the models is significant (the F-value of each model is greater than 3.68) and each of the coefficients is significant (the $\mathrm{t}$-statistic for each variable is greater than 2.131). Confidence probability is 0.05 .

Source: calculated by the authors by using the data from Labour and Employment Statistics. Official Web-Site of the Committee on Statistics of Ministry of National Economy of the Republic of Kazakhstan. Retrieved from: https://stat.gov.kz/official/ industry/25/statistic/8; Price Statistics. Official Web-site of the Committee on Statistics of Ministry of National Economy of the Republic of Kazakhstan. Retrieved from: https://stat.gov.kz/official/industry/26/statistic/8; Demographic Statistics. Retrieved from: https://stat.gov.kz/official/industry/61/statistic/8 ; Quality of Life Statistics. Retrieved from: https://stat.gov.kz/official/industry/64/ statistic/8 ; Statistical Reports. Information Service of the Committee on the Legal Statistics and Special Accounts of the State Office of Public Prosecutor of the Republic of Kazakhstan. Retrieved from: https://qamqor.gov.kz/portal/page/portal/POPageGroup/ Services/Pravstat; Statistical yearbooks 'Public Health in the Republic of Kazakhstan and Activities of Health Care Organizations' Republican Center for Health Development. Retrieved from: http://www.rcrz.kz/index.php/ru/?option=com content\&view=arti$\underline{\text { cle\&id }=973}$ 
Table 8

Regression power equations by region

\begin{tabular}{|l|c|c|c|}
\hline \multicolumn{1}{|c|}{ Region } & $\boldsymbol{X}_{\mathbf{1}}$ & $\boldsymbol{X}_{\mathbf{2}}$ & Equation \\
\hline Akmola region & DpM & MD & $Y=40 \cdot X_{1}^{0.11} \cdot X_{2}^{-0.03}$ \\
\hline Aktobe region & NMI & SM & $Y=33.1 \cdot X_{1}^{0.05} \cdot X_{2}^{0.02}$ \\
\hline Almaty region & MD & DpM & $Y=49.4 \cdot X_{1}^{-0.04} \cdot X_{2}^{0.8}$ \\
\hline Atyrau region & NMI & DpM & $Y=28.8 \cdot X_{1}^{0.041} \cdot X_{2}^{0.074}$ \\
\hline Western Kazakhstan & NMI & CR & $Y=29.4 \cdot X_{1}^{0.04} \cdot X_{2}^{0.075}$ \\
\hline Jambyl region & SM & DpM & $Y=36.2 \cdot X_{1}^{0.03} \cdot X_{2}^{0.065}$ \\
\hline Karaganda region & MD & SM & $Y=54.6 \cdot X_{1}^{-0.03} \cdot X_{2}^{0.04}$ \\
\hline Kostanay region & MD & DPM & $Y=36.6 \cdot X_{1}^{-0.04} \cdot X_{2}^{0.13}$ \\
\hline Kyzylorda region & DpM & U & $Y=44.7 \cdot X_{1}^{0.08} \cdot X_{2}^{-0.04}$ \\
\hline Mangistau region & U & MD & $Y=103.5 \cdot X_{1}^{-0.09} \cdot X_{2}^{-0.04}$ \\
\hline Pavlodar region & MD & DpM & $Y=59.7 \cdot X_{1}^{-0.035} \cdot X_{2}^{0.056}$ \\
\hline Northern Kazakhstan & DpM & MD & $Y=37.3 \cdot X_{1}^{0.12} \cdot X_{2}^{-0.028}$ \\
\hline Turkestan region and Shymkent & SM & NMI & $Y=38.9 \cdot X_{1}^{0.13} \cdot X_{2}^{-0.06}$ \\
\hline Eastern Kazakhstan & CSD & BD & $Y=46.1 \cdot X_{1}^{0.12} \cdot X_{2}^{-0.07}$ \\
\hline Nur-Sultan & NMI & no data & $Y=46.1 \cdot X_{1}^{0.039}$ \\
\hline Almaty & SM & HW & $Y=15.3 \cdot X_{1}^{0.039} \cdot X_{2}^{0.012}$ \\
\hline
\end{tabular}

The factors that occur most frequently in regression models are as follows: the number of divorces per 1,000 marriages, 9 times; substance-induced mental disorders, 7 times; nominal per capita income, 5 times; subsistence minimum, 5 times; unemployment, twice; number of health workers, once; morbidity rates of blood diseases, once, and morbidity rates of circulatory system diseases, once.

Thus, we can conclude that the most significant factors in terms of scope are economic ones such as income and subsistence minimum. Among other factors that influence life expectancy are the demographic ones, such as the ratio of divorces to marriages, and medical ones, especially those related to mental health such as the rate of substance-induced mental disorders. To forecast life expectancy in relation to these factors we used regression power equations shown in Table 8.

\section{Conclusions}

To evaluate the factors affecting life expectancy in regions of Kazakhstan, we used a modified methodology. To investigate the relationship between life expectancy and socio-economic factors in Kazakhstan, we selected a set of indicators and calculated correlation coefficients for each region and each indicator. Indicators with coefficients below the threshold were excluded. Factors with the strongest influence on life expectancy were selected by applying two-factor power regression models based on the Cobb-Douglas production function. As a result, we have found the most significant factors affecting life expectancy in Kazakhstan and built models for short- and midterm forecasting of life expectancy.

Our calculations have led us to the conclusion that economic factors have the strongest influence on life expectancy. These factors determine financial well-being of people in Kazakhstan and, therefore, correlate with the overall quality of life, which includes housing conditions, food, opportunities for recreation, access to medical and educational services.

Our regression models of life expectancy often include such indicators as the number of divorces per 1,000 marriages and the rate of substance-induced mental disorders. In some regions health-related indicators come to the fore. It can be supposed that after a certain level of socio-economic development is reached, other factors related to the quality of life and life expectancy start to gain prominence. Forecasting such developments can prove useful for strategy- and policy-makers aiming to extend life expectancy in the long term.

It should be noted that the proposed models are most suitable for 7 - to 10 -year forecasts while long-term forecasts will be less accurate as they will not take into consideration those factors that were not included in the models. This means that forecasts need to be adjusted with the help of additional methods. 


\section{References}

Glushakov, A.I. (2004) Indicator 'Life Expectancy': Definition, Methods of Calculation and Analysis. Obschestvennoe zdorovye i zravookhranenie, (1), 12-16.

Shabunova, A.A., Rybakova, N.A., \& Tikhomirova, G.V. (2009) Determinants of Public Health in Regions (the Case of Vologda Region). Sotsiologicheskie issledovania, (8), 85-91.

Timashev, S.A., Voronina, L.N., \& Makarova, M.N. (2013). Methodological Approach to Evaluation of the Impact of State Expenditures on Extending Life Expectancy (the Case of Ekaterinburg). Zhurnal ekonomicheskoy teorii, (3), 284-288.

Novoselova, E.N. (2016). Key Factors of Life Expectancy in Megapolises (the Case of Moscow). Journal of the Moscow State University. Series 18. Social and Political Studies, (2), 176-200. doi: 10.24290/1029-3736-2016-22-2-176-200

Kabanov, V.N. (2015) Evaluation of the Efficiency of State Investment in Longevity. Ekonomicheskie i sotsialnye peremeny: fakty, tendentsii, prognoz, 5(41), 75-88. doi: 10.15838/esc/2015.5.41.5

Andrianov, K.V. (2019). Statistical Analysis of the Relationship between Indicators of Health Care Development and Life Expectancy. Proceedings of the National Conference 'Results of Reforms, Prospects of Development of Auditing and its Role in Economic Security'. Tyumen: Publishing House of Tyumen State University, 2019, 79-86.

Kulak, A.G. (2016). Statistical Analysis of the Factors Influencing the Dynamics of Life Expectancy in the Republic of Belarus. Sistemnoye upravlenie, 1. Retrieved from: http://sisupr.mrsu. $\underline{\mathrm{ru} / 2016-2 / \mathrm{PDF} / \text { Kulak.pdf }}$

Zvezdina, N.V., \& Ivanov, L.V. (2015). Life Expectancy in Russia and its Determinants. Voprosy statistiki, (7), 10-20.

Omarova, A.I., Saubetova, B.S., \& Taskaraeva, M.B. (2019). Quality of Life in Kazakhstan. Sotsialnye i ekonomicheskie sistemy, 1(7), 155-173.

Sraubaev, E.N., \& Serik, B. (2013). Development of Technologies of Health Care Management Based on the Integral Evaluation of Combined Impact of Environmental Factors. Gigiena i sanitaria, (5), 73-75.

Taskinbajkyzy, Z., Utebalieva, D., \& Tasbolatova, A. (2019) Health as an Indicator of Life Quality in Kazakhstan. Sotsialnye i ekonomicheskie sistemy, (8), 31-46.

Palevskaya, S.A., \& Kasymzhanova, A.T. (2019). Program-Based Approach as an Organizational Technology of Health Protection (the Case of Program 'Densaulyk' (Health), Kazakhstan). Uralsky meditsinsky zhurnal, (182), 131-136.

Esenbekova, A.B. (2017). Analysis of the Main Socio-Economic Indicators of the Quality of Life in Relation to the Global Climate Change in the Republic of Kazakhstan and Kyrgyz Republic. Central Asian Economic Review, 2(117), 90-100.

Sagitova, G. K. (2018). Analysis of Factors Affecting the Quality of Life in the Republic of Kazakhstan. In G.B. Kleyner, S.E. Schepetov (Eds) Systemny analiz v ekonomike (pp. 323-326). Moscow: Prometey. DOI: 10.33278/SAE-2018.rus.323-326

Shelomentseva, V.P., Sartay, A.K., \& Utegenova, A.N. (2019). Health Care Improvement in Kazakhstan as the Necessary Condition of Social Security. Proceedings of the Conference 'Social Security in Eurasia', (1), 103-105.

Baykova, E.I. (2018) Enhancing Quality of Life in Kazakhstan in the Context of Economic Security. Proceedings of the Conference 'Key Elements of Development of Human Potential, Economy and Economic Security Provision', 1, 56-60.

Rakhmetova, R.U., \& Andekina, R.E. (2018) Regional Characteristics of Demographic Forecasting in Kazakhstan. Sotsiosfera, (3), 113-118.

Nurlanova, N.K., Dnishev, F.M., \& Brimbetova, N.Z. (2019). Scenarios and Causes of Economic Modernization of Kazakhstani Regions. Ekonomika i finansy (Uzbekistan), (1), 32-40. 
Molchanova, E.V., \& Kruchek, M.M. (2013) Mathematical Methods of Evaluation of Factors Affecting Public Health in Russian Regions (Panel Analysis). Sotsialnye aspekty zdorovia naselenia, (5). Retrieved from: http://vestnik.mednet.ru/content/view/513/30/

Moiseev, N.A., \& Romannikov, A.N. (2017) Analysis of the Efficacy of Methods of Regression Equation Specification. Ekonomichesky zhurnal, (45), 87-110.

\section{Information about the authors}

Aksanat Zh. Panzabekova - Deputy Director for Science, Institute of Economics of the Science Committee of the Ministry of Education and Science of the Republic of Kazakhstan (29 Kurmangazy str., 050000 Almaty, Kazakhstan); e-mail: panzabekova.aksana@ieconom.kz

Ivan E. Digel - Junior Researcher, Institute of Economics of the Science Committee of the Ministry of Education and Science of the Republic of Kazakhstan (29 Kurmangazy str., 050000 Almaty, Kazakhstan); e-mail: ivan.digel@gmail.com

ARTICLE INFO: received September 3, 2020; accepted December 1, 2020

\section{Информация об авторах}

Панзабекова Аксанат Жакитжановна - заместитель директора по науке, Институт экономики Комитета науки Министерства образования и науки (Казахстан, 050000 Алматы, ул. Курмангазы, 29), e-mail: panzabekova.aksana@ieconom.kz

Дигель Иван Евгеньевич - младший научный сотрудник, Институт экономики Комитета науки Министерства образования и науки (Казахстан, 050000 Алматы, ул. Курмангазы, 29); e-mail: ivan.digel@gmail.com

ИНФОРМАЦИЯ О СТАТЬЕ: дата поступления 3 сентября 2020 г.; дата принятия к печати 1 декабря 2020 г. 